\title{
Distribuição espacial de minerais pesados nos sedimentos superficiais da Plataforma Continental Oeste do Ceará, Nordeste do Brasil
}

\author{
Antônio Borges de AGUIAR NETO ${ }^{1}$, Wanessa Sousa MARQUES ${ }^{2}$ \& George Satander Sá FREIRE ${ }^{3}$ \\ 1 Universidade Federal do Ceará. Vila Carlos Vasconcelos, n² 2445A, Joaquim Távora, CEP 60.135-182, Fortaleza, CE, Brasil. E- \\ -mail: tonygeoufc@hotmail.com. \\ 2 Serviço Geológico do Brasil, CPRM. Av. Antônio Sales, 1418, Joaquim Távora, CEP 60.135-101, Fortaleza, CE, Brasil. E-mail: \\ wsmarq@yahoo.com.br. \\ 3 Departamento de Geologia, Universidade Federal do Ceará, Campus do Pici. Caixa Postal 6.011, CEP 60.455-900, Fortaleza, \\ CE, Brasil. E-mail: freire@ufc.br. \\ Recebido em 12/2014. Aceito para publicação em 01/2016. \\ Versão online publicada em 23/02/2016 (www.pesquisasemgeociencias.ufrgs.br)
}

\begin{abstract}
Resumo - Os sedimentos da plataforma continental oeste cearense foram investigados com relação à sua textura, conteúdo de carbonato de cálcio e minerais pesados com a geração do modelo digital de fundo desta plataforma. A estatística multivariada foi aplicada aos dados mineralógicos para auxiliar na interpretação da proveniência dos minerais pesados. A plataforma continental oeste cearense, apesar da predominância da sedimentação carbonática, apresenta concentrações importantes de minerais pesados (4,54\%), originando depósitos do tipo plácer nas areias litoclásticas e litobioclásticas situadas mais a leste da área estudada (Folha Fortaleza). Foram identificadas irregularidades indicativas de paleocanais e antigas linhas de praia que favorecem a concentração de minerais pesados. A assembleia mineral (ilmenita, turmalina, epídoto, hornblenda, monazita, estaurolita, sillimanita, rutilo, magnetita, zircão, andaluzita, cianita, granada, leucoxênio, diopsídio, apatita, espinélio e cassiterita) sugere contribuições regionais do retrabalhamento dos sedimentos da Formação Barreiras e contribuição local das rochas metamórficas do Complexo Ceará. Afloramentos do embasamento cristalino na plataforma continental próximos ao Porto do Pecém (São Gonçalo do Amarante) contribuem diretamente no aporte de sedimentos terrígenos e são nesses locais que os minerais pesados se concentram. A estatística multivariada discriminou os dois tipos de proveniências anteriormente descritos, contudo devem-se levar em consideração outras contribuições como das areias pretas costeiras, aporte fluvial atual (continental) e pretérito (vales fluviais afogados) e sedimentos marinhos de deriva litorânea.

Palavras-chave: transporte sedimentar, minerais detríticos, geologia marinha, proveniência.
\end{abstract}

Abstract- SPATIAL DISTRIBUTION OF HEAVY MINERALS IN THE SUPERFICIAL SEDIMENTS OF THE WESTERn CEARÁ Continental Shelf, NoRTHEaST OF BRAZIL. The continental shelf sediments of the west coast of Ceará were investigated about their texture, calcium carbonate and heavy minerals with the generation of digital bottom model of this shelf. Multivariate statistics analyses were applied for mineralogical data to aid interpretation of heavy mineral provenance. Despite the predominance of carbonate sedimentation, the western Ceará continental shelf presents significant concentrations of heavy mineral ( $4.54 \%$ ), resulting in placer deposits in litoclastic and litobioclastic sands located further east of the study area (Fortaleza Chart). It was possible identify irregularities in the submarine bottom, which indicate paleochannels and ancient shoreline and support heavy minerals concentration. The mineral assemblage (ilmenite, tourmaline, epidote, hornblende, monazite, staurolite, sillimanite, rutile, magnetite, zircon, andalusite, kyanite, garnet, leucoxene, diopside, apatite, spinel and cassiterite) suggests regional contributions of the reworking of sediments Barreiras Formation and local contribuition of metamorphic rocks of Ceará Complex. Crystalline basement outcrops on the continental shelf near Pecém Port (São Gonçalo do Amarante) contribute directly to sediment supply of terrigenous, hence the heavy minerals are concentrated in these places. Multivariate statistics distinguish two types of sources which were described above, however it should take attention to other contributions as coastal black sands, present fluvial supply (continental), past fluvial supply (drowned river valleys) and marine sediments from longshore drift.

Keywords: sedimentary transport, detrital minerals, marine geology, provenance. 


\section{Introdução}

Os depósitos de minerais pesados ( $\mathrm{d}>2,89$ ), com densidade superior aos dos minerais feldspato e quartzo, foram, provavelmente, um dos primeiros recursos minerais marinhos explorados pelo homem. Lewis (1924) relata que os fenícios transportavam depósitos praiais de cassiterita na região de Cornwall (Inglaterra) para o porto de Cadiz (Espanha) no período entre 1000 e 200 anos $\mathrm{AC}$, fornecendo estanho às margens do Mar Mediterrâneo, que era transportado possivelmente até a Índia.

As coberturas sedimentares quaternárias mais favoráveis à concentração de minerais pesados são as areias retrabalhadas de plataforma continental e as areias fluviais retrabalhadas (Emery \& Noakes, 1968). Geralmente não excedem a concentração $0,1 \%$ a $0,5 \%$ das frações terrígenas e a assembleia desses minerais pesados constitui fonte de dados para: proveniência dos sedimentos, histórias do intemperismo, transporte e correlação paleogeográfica (Suguio, 2003). A partir da decomposição e erosão de rochas-fonte ígneas, metamórficas ou sedimentares, esses minerais são concentrados mecanicamente originando os depósitos do tipo pláceres, que podem formar acumulações sedimentares de valor econômico.

Os pláceres marinhos têm íntima relação com as variações eustáticas do nível do mar durante o Quaternário, oscilando entre exposição das plataformas continentais e afogamento das mesmas (Kudrass, 2000; Silva, 2000; Lalomov \& Tabolitch, 2000; Gent et al., 2005; Tomazzoli et al., 2007; Corrêa et al., 2008; Addad, 2010; Cavalcanti, 2011). Como resultado dessas oscilações, uma notável quantidade de pláceres foi formada em períodos de nível de mar baixo, localizando-se em feições como vales fluviais afogados e antigas linhas de praias. Alguns desses depósitos, especialmente os ocorrentes na plataforma continental interna, são retrabalhados e redistribuídos pela hidrodinâmica atual.

Alguns dos trabalhos pioneiros sobre esses depósitos na plataforma continental cearense (Barreto et al., 1975; França et al., 1976) constataram locais com ocorrência abundante de minerais pesados que os autores denominaram de províncias: a província da cianita nas proximidades do delta do Rio Jaguaribe; a província da hornblenda nas praias e dunas de Fortaleza, predominando entre os opacos nas duas províncias a ilmenita; e na região entre a fronteira do Estado do Piauí e a foz do Rio Acaraú predominam granada, hornblenda, turmalina e epídoto.
Este artigo mostra as concentrações de minerais pesados nos sedimentos superficiais da plataforma continental oeste do Estado do Ceará com base em análise de dados multivariada, proveniências, morfologia e faciologia.

\section{2 Área, materiais e métodos}

Essa pesquisa foi desenvolvida em parte da plataforma continental cearense, até a profundidade de -30 m, entre os municípios de Caucaia e a divisa com o Estado do Piauí, pela articulação das cartas Bitupitá, Acaraú, Itarema e Fortaleza (Fig. 1). A plataforma continental cearense tem largura média de $63 \mathrm{~km}$, máxima de $101 \mathrm{~km}$ no extremo oeste do Estado e mínima de $41 \mathrm{~km}$ no extremo leste.

\subsection{Caracterização climática e oceanográfica da área}

A zona costeira do Ceará é influenciada pelos regimes climáticos Tropical Quente Semi-Árido Brando e Tropical Quente Subúmido, onde atua a Zona de Convergência Intertropical (ZCIT). Apresenta altas taxas de insolação, temperatura média anual de $26,9^{\circ} \mathrm{C}$ com variações inferiores a $5^{\circ} \mathrm{C}$ e umidade relativa do ar variando de 83,9\% em março a $74 \%$ em setembro. A pluviosidade concentra-se em quatro meses consecutivos, geralmente de fevereiro a maio, com média anual de $1.440 \mathrm{~mm}$.

A atuação dos ventos, ondas, marés e correntes litorâneas condicionam a dinâmica em ambientes costeiros e marinhos pela distribuição dos sedimentos, processos erosivos e deposicionais, influenciando na concentração de grãos de minerais pesados. Na área de estudo, a velocidade média dos ventos varia de 3,40 a 9,57 m/s de acordo com a estação anemográfica em Pecém, município de São Gonçalo do Amarante. As direções dominantes são de Leste, representando 46,3 \% das medidas, seguida das direções ENE com 22,3 \% e ESE com 16,0 \% das ocorrências e estão relacionadas à ação do Anticiclone Sul que diminui no Norte e Nordeste do Brasil, passando para a atuação da ZCIT. As correntes litorâneas alcançam velocidade média entre 0,23 e $0,24 \mathrm{~m} / \mathrm{s}$ de direção geral NW na superfície e $0,21 \mathrm{~m} / \mathrm{s}$ de direção $\mathrm{W}$ no fundo. São responsáveis pelo transporte de sedimentos que atinge a costa em um determinado ângulo que, de acordo com Silva (2005), o ângulo de incidência dessas correntes determina a velocidade e trajetória do transporte de sedimentos. As marés são de caráter semidiurno, podendo variar entre $0,75 \mathrm{e}$ 3,23 m. 


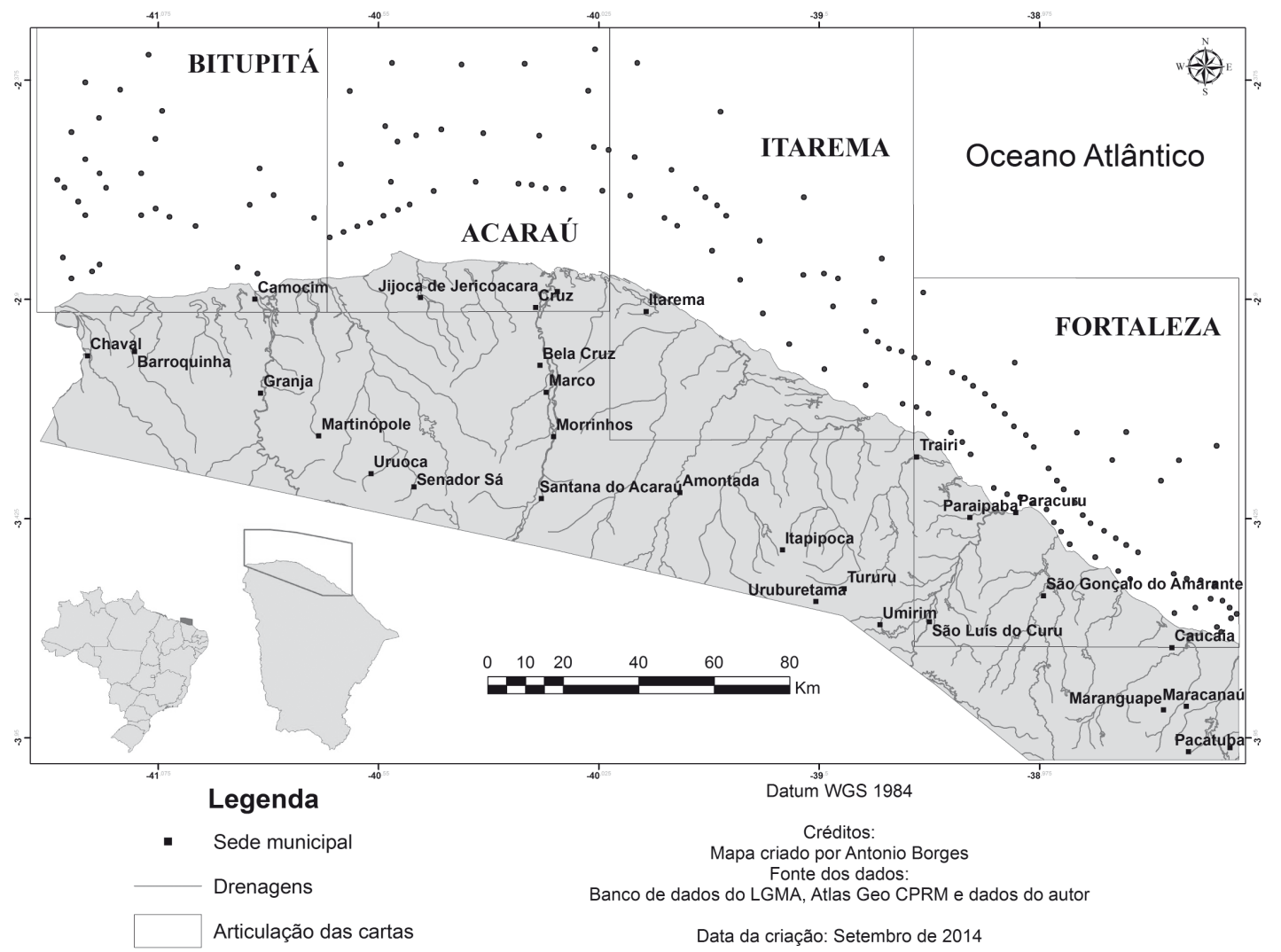

Figura 1. Área de estudo com articulação das cartas e pontos de amostragem.

\subsection{Contexto geotectônico e geológico da área}

As bacias sedimentares da zona costeira do Nordeste oriental brasileiro e da margem equatorial atlântica tem como embasamento estruturas da Província Borborema. A Província Borborema é caracterizada como um complexo mosaico separado por falhas ou altos do embasamento, resultado da convergência dos crátons São Luís-Oeste Africano, São Francisco-Congo e Amazônico, que estiveram envolvidos na amalgamação e consequente formação do Gondwana. A Província Borborema e a parte oriental da margem equatorial adjacente englobam uma série de bacias inicialmente intracontinentais, submetidas a um estiramento difuso durante o Eocretáceo. Essa deformação foi caracterizada pelos principais fenômenos tectonosedimentares e magmáticos que culminaram com a abertura do Oceano Atlântico Sul (Conceição et al., 1988).

A área de estudo está inserida na Bacia do Ceará, limitada a leste pelo Alto de Fortaleza e a oeste pelo Alto de Tutóia com uma área de 35.000 $\mathrm{km}^{2}$. Três segmentos são reconhecidos na bacia de oeste para leste: as sub- bacias de Piauí-Camocim, Acaraú-Icaraí e Mundaú que caracterizam diferentes domínios separados por importantes feições transversais positivas, correspondentes a altos do embasamento, a grandes corpos ígneos ou a anti- clinais em ampla escala produzidos por inversão tectônica sinsedimentar. A fase rifte acomodou mais de $4.000 \mathrm{~m}$ de sedimentos siliciclásticos continentais naquele segmento da margem, correspondentes à fácies de rochas aluviais, fluviais e lacustres da Formação Mundaú. A partir do Albiano, passaram a dominar condições francamente marinhas. Entre o Eoceno e o Recente, uma sedimentação arenosa grossa acomodou-se junto às áreas proximais da bacia, a Formação Tibau, que grada para os carbonatos da Formação Guamaré e aos folhelhos da Formação Ubarana no sentido das porções mais distais da bacia (Milani et al., 2001).

A plataforma continental cearense apresenta sedimentação predominantemente bioclástica (carbonática algálica), com contribuições de até 75 $\%$. Os sedimentos siliciclásticos estão mais presentes na plataforma continental interna e defronte a Fortaleza chegam até a borda da plataforma continental (Martins \& Coutinho, 1981; Freire, 1985; Silva Filho, 2004).

\subsection{Materiais e métodos}

Foram analisadas 147 amostras de sedimentos de fundo da plataforma continental (Fig. 1) oriundas da Litoteca do Laboratório de Geologia Marinha e Aplicada (LGMA) da Universidade Federal do Ceará (UFC). Essas amostras de sedimentos 
foram coletadas nas campanhas oceanográficas Geomar XVIII (1981), Geocosta II (1994) e GRANMAR CE (2008) mediante o uso do amostrador pontual do tipo "Van-Veen" da linha de costa de Fortaleza até a fronteira do Estado do Piauí, limitando-se a isóbata de $30 \mathrm{~m}$. Foram utilizados o barco de pesquisa Professor Martins Filho, da UFC, e o navio balizador Comandante Manhães, da Marinha do Brasil. Os dados de minerais pesados de Almeida et al. (2011) estão incluídos neste estudo.

A análise granulométrica foi realizada segundo o método tradicional de peneiramento a úmido, seguido por peneiramento seco e pipetagem. Após a obtenção das várias frações que compõem os sedimentos, prosseguiu-se com a classificação textural das amostras com o programa ANASED.

0 teor de $\mathrm{CaCO}_{3}$ foi determinado pelo método do Calcímetro de Bernard (Lamas et al., 2005, modificado). Esse dado é integrado à análise granulométrica para definir as fácies dos sedimentos segundo a classificação de Larsounner (1977).

A separação dos minerais pesados seguiu os procedimentos metodológicos estabelecidos por Parfenoff et al. (1970) com separação densimétrica da fração entre $0,250 \mathrm{~mm}$ a $0,062 \mathrm{~mm}$ (faixa granulométrica com maior concentração de minerais pesados) utilizando o bromofórmio $\left(\mathrm{CHBr}_{3}\right.$, $\mathrm{d}=2,89$ ) e separação magnética com ímã de mão para discriminação das magnetitas. A identificação e quantificação das espécies minerais foram rea- lizadas utilizando lupa binocular pela contagem de 300 grãos minerais de acordo com Galehouse (1971), observando as características intrínsecas de brilho, clivagem, cor e hábito de cristalização.

As amostras com maiores concentrações de minerais pesados foram submetidas à análise por microscopia eletrônica de varredura (MEV) com sistema de detecção de raios X por dispersão em energia (EDS - Energy Dispersive System) para obter imagens de alta resolução desses grãos e otimizar a identificação dos minerais pesados.

O mapa faciológico da plataforma continental oeste do Ceará foi confeccionado mediante o uso do software Arcgis 10.1 a partir dos dados granulométricos e do conteúdo de $\mathrm{CaCO}_{3}$ nos sedimentos, delimitando as diversas fácies sedimentares na plataforma continental. 0 modelo digital do terreno (MDT) foi elaborado utilizando o Surfer 10 pelo método de Krigagem e ajuste de variograma (Fig. 2) através de 1687 cotas batimétricas (Fig. 3).

Os teores de 14 espécies de minerais pesados foram comparados utilizando as técnicas estatísticas multivariadas Análise de Componentes Principais (ACP), de Agrupamento e de Fatores utilizando o software Statistica 7.0. Essas técnicas permitem descrever o comportamento da distribuição da maior parte dos sedimentos, representar processos geológicos atuantes e ocorrências de paragêneses minerais (Andriotti, 1997; Corrêa et al., 2008).

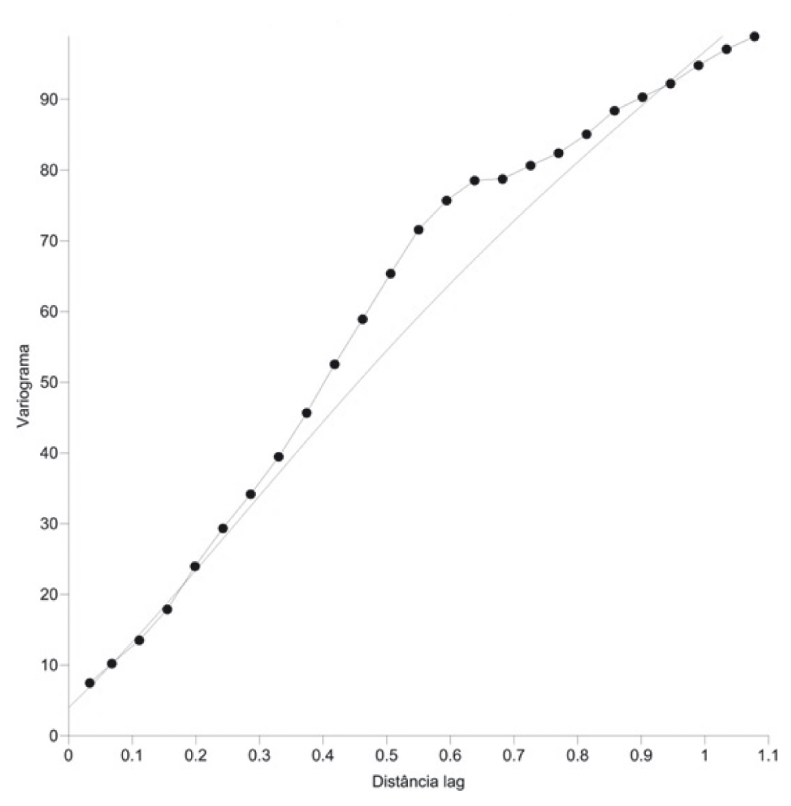

Figura 2. Variograma ajustado na modelagem da morfologia de fundo da plataforma continental estudada. 


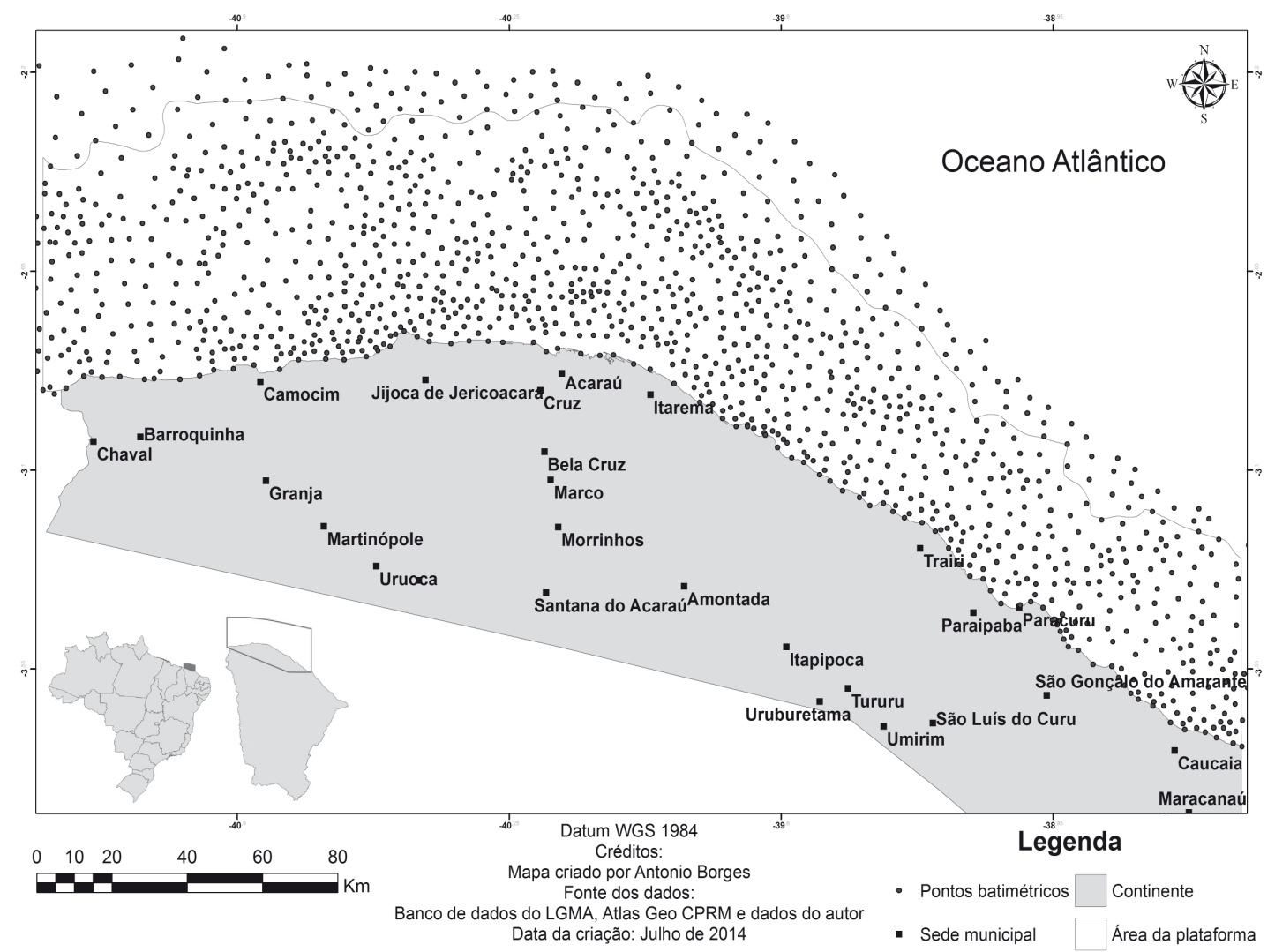

Figura 3. Malha amostral para geração do MDT da plataforma continental estudada.

\section{Resultados}

Foram discriminadas nove fácies na plataforma continental oeste do Ceará: areia litoclástica média a fina, areia litoclástica grossa, areia litobioclástica média a fina, areia litobioclástica grossa, areia biolitoclástica média a fina, areia biolitoclástica grossa, areia bioclástica média a fina, areia bioclástica grossa e cascalho bioclástico (Fig. 4). Foi observada uma maior contribuição terrígena na parte mais a leste e biodetrítica a oeste. A heterogeneidade marca a distribuição do tamanho dos grãos, ocorrendo ilhas tanto para os terrígenos (litoclásticos e litobioclásticos) grossos e finos, como para os biodetríticos (bioclásticos e biolitoclásticos), relevando o efeito da hidrodinâmica na plataforma continental.

0 modelo digital do terreno (MDT) revelou a ocorrência de irregularidades na morfologia de fundo, principalmente a partir de $20 \mathrm{~m}$ de profundidade, assim como uma tendência de alargamento da plataforma continental de Leste para Oeste (Fig. 5). Essas feições abruptas no fundo marinho propiciam o aprisionamento de minerais pesados que ficam retidos nesses locais e caracterizaram níveis de mar mais baixo (antigas linhas de praia e paleocanais).

Os teores de minerais pesados variaram de $0,00 \%$ a 4,54 \% na fração analisada $(0,250$ a 0,062 mm, areia média a muito fina), com notável concentração desses depósitos na carta Fortaleza e em profundidades inferiores a $20 \mathrm{~m}$ (Fig. 6). Foram identificadas 18 espécies de minerais pesados na seguinte ordem de abundância: ilmenita, turmalina, epídoto, hornblenda, monazita, estaurolita, sillimanita, rutilo, magnetita, zircão, andaluzita, cianita, granada, leucoxênio, diopsídio, apatita, espinélio e cassiterita (Tab. 1). Ilmenita (40,23\%) e turmalina $(25,59 \%)$ são as únicas espécies que ocorrem em toda a plataforma continental, exceto naquelas com $0,00 \%$ de minerais pesados, e juntas, representam mais da metade da assembleia mineral ocorrente na plataforma continental, exceto defronte à Fortaleza onde ocorre um decréscimo dessas espécies, tornando a aumentar na direção leste (Figs. 7 a 10). É perceptível o aumento de epídoto, hornblenda, monazita, sillimanita e andaluzita na direção Leste. Os minerais pesados leucoxênio, apatita e diopsídio ocorrem de maneira muito restrita nas folhas Bitupitá e Acaráu. Já os minerais pesados estaurolita, rutilo e cianita apresentam maiores distribuições nas cartas Bitupitá e Fortaleza. A magnetita e o zircão têm suas ocorrências mais bem marcadas nas cartas Acaraú e Fortaleza. A granada tem maior contribuição na assembleia da carta Fortaleza, enquanto espinélio e cassiterita não são representados graficamente devido seus baixos teores e distribuição. 


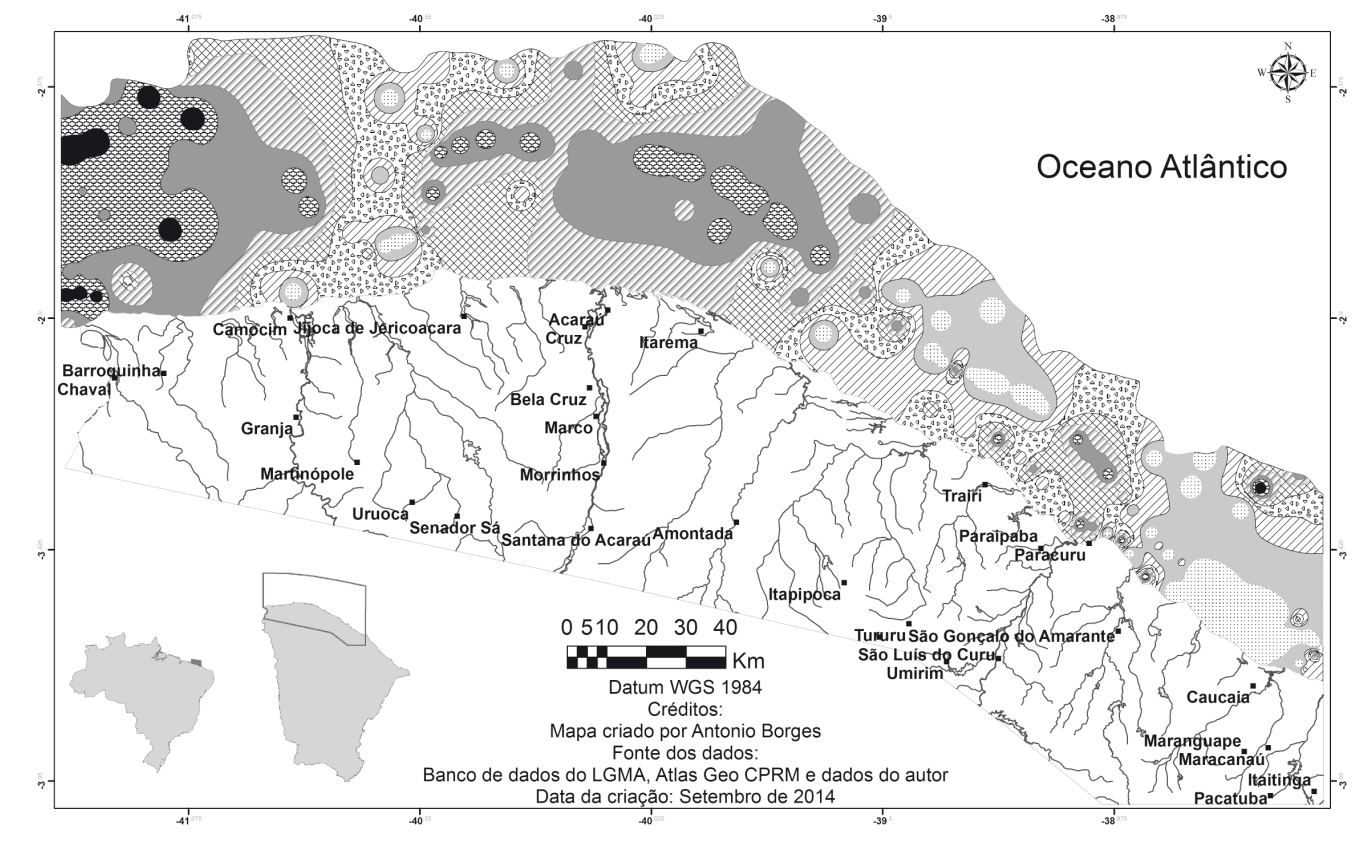

\section{Fácies sedimentares plataformais}

- Sede municipal $\int$ Areia litoclástica grossa Areia biolitoclástica média a fina 4 Areia bioclástica média a fina

Drenagens Areia litoclástica média a fina Areia litobioclástica grossa Ara biolitoclástica grossa Ara Cascalho bioclástico

Figura 4. Mapa de fácies da plataforma continental estudada.

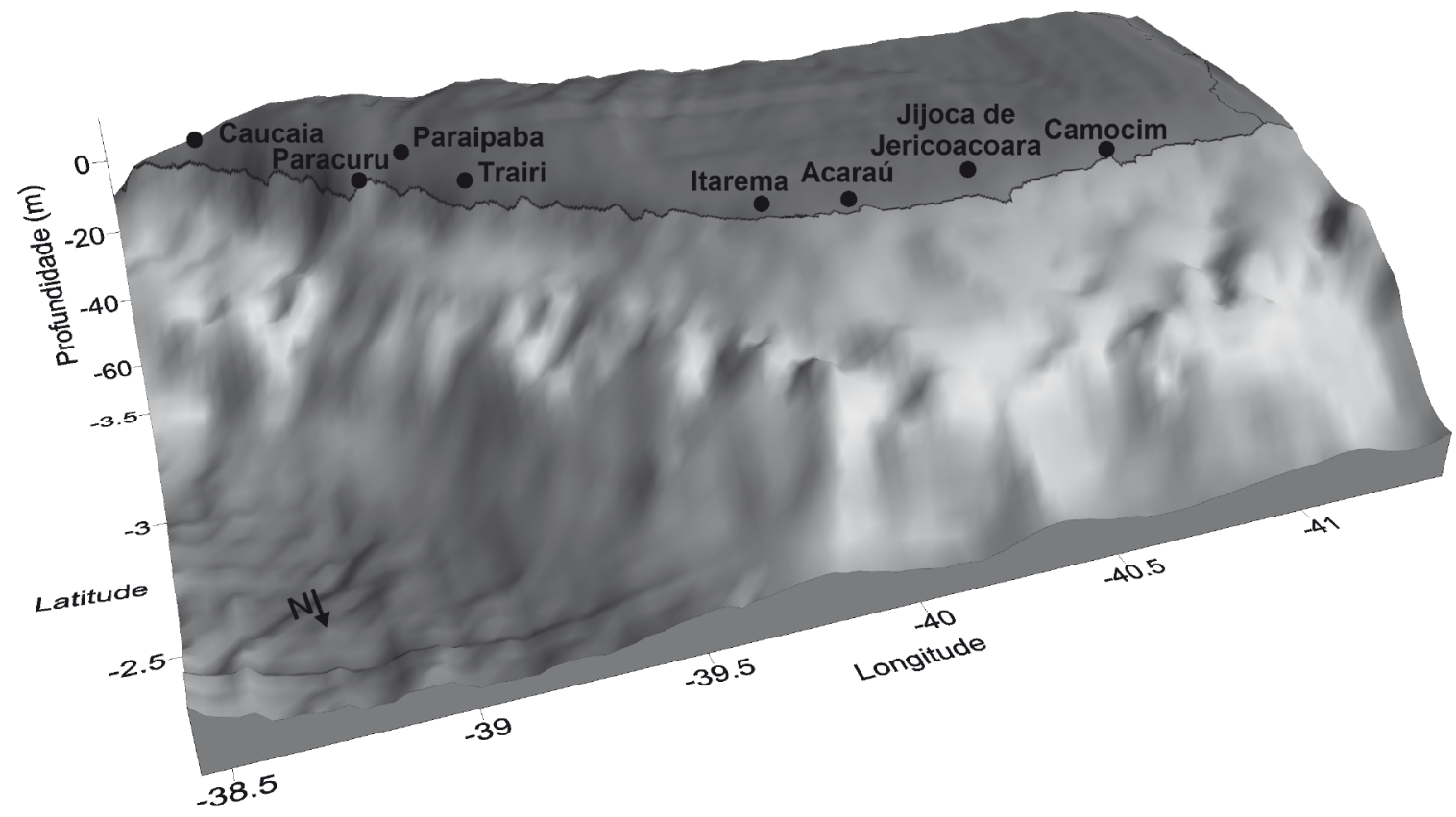

Figura 5. Modelo Digital do Terreno da plataforma continental estudada. 


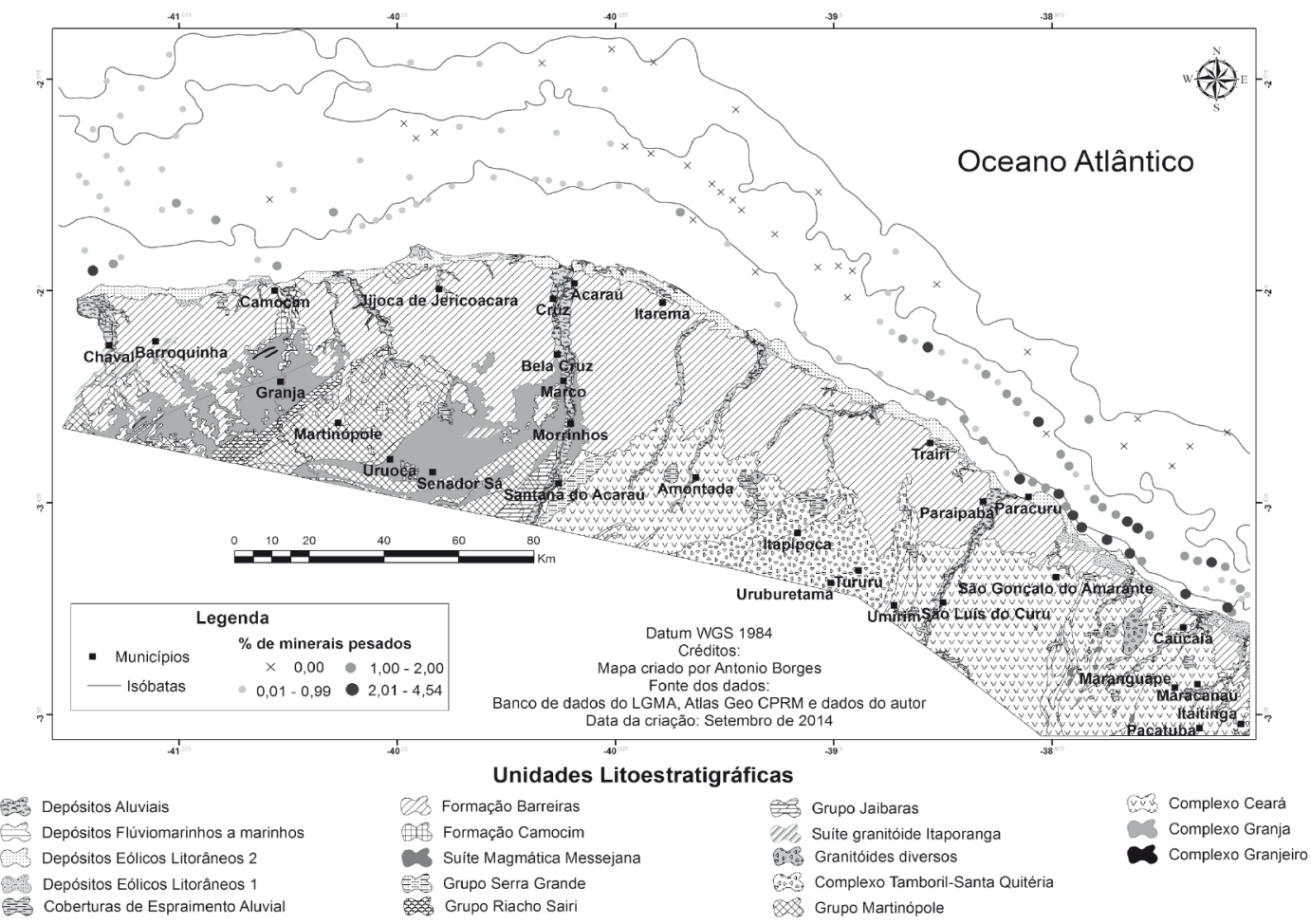

Figura 6. Mapa geológico continental e percentual total de minerais pesados na plataforma continental oeste cearense. (Fonte: Atlas Geo CPRM, Banco de dados do LGMA e dados do autor)

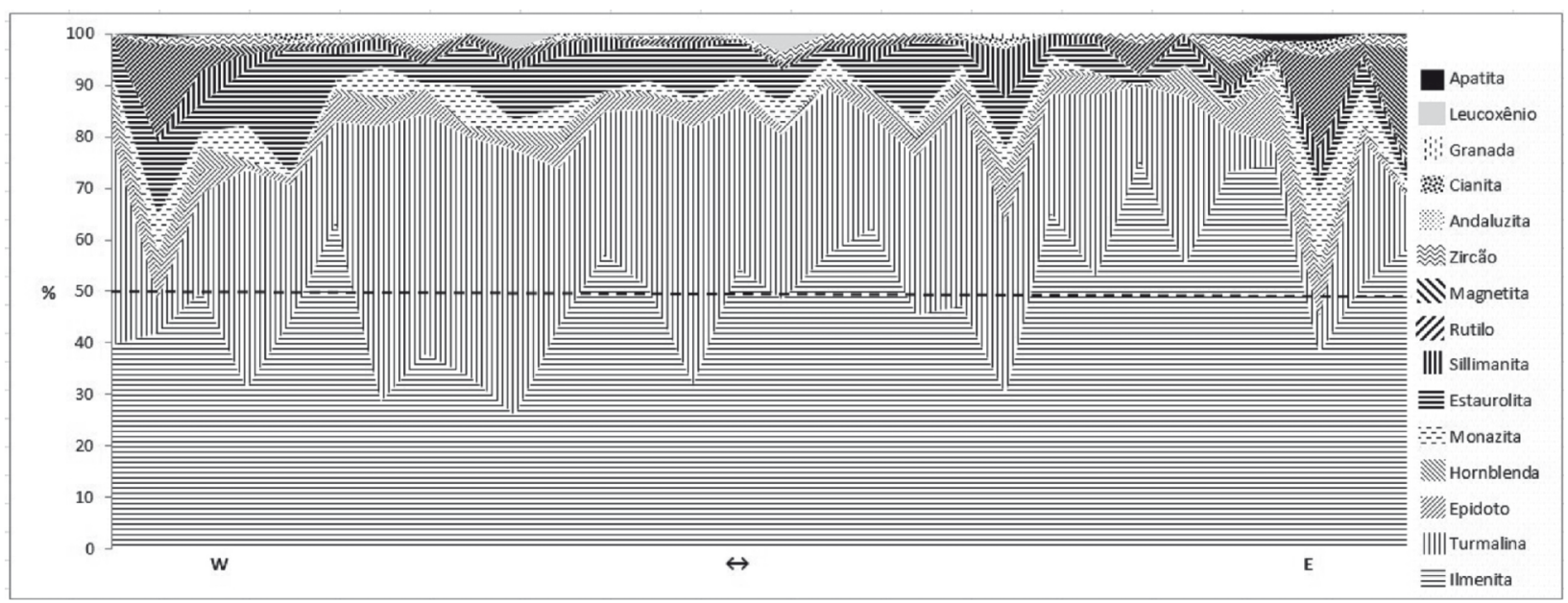

Figura 7. Distribuição de minerais pesados da Folha Bitupitá.

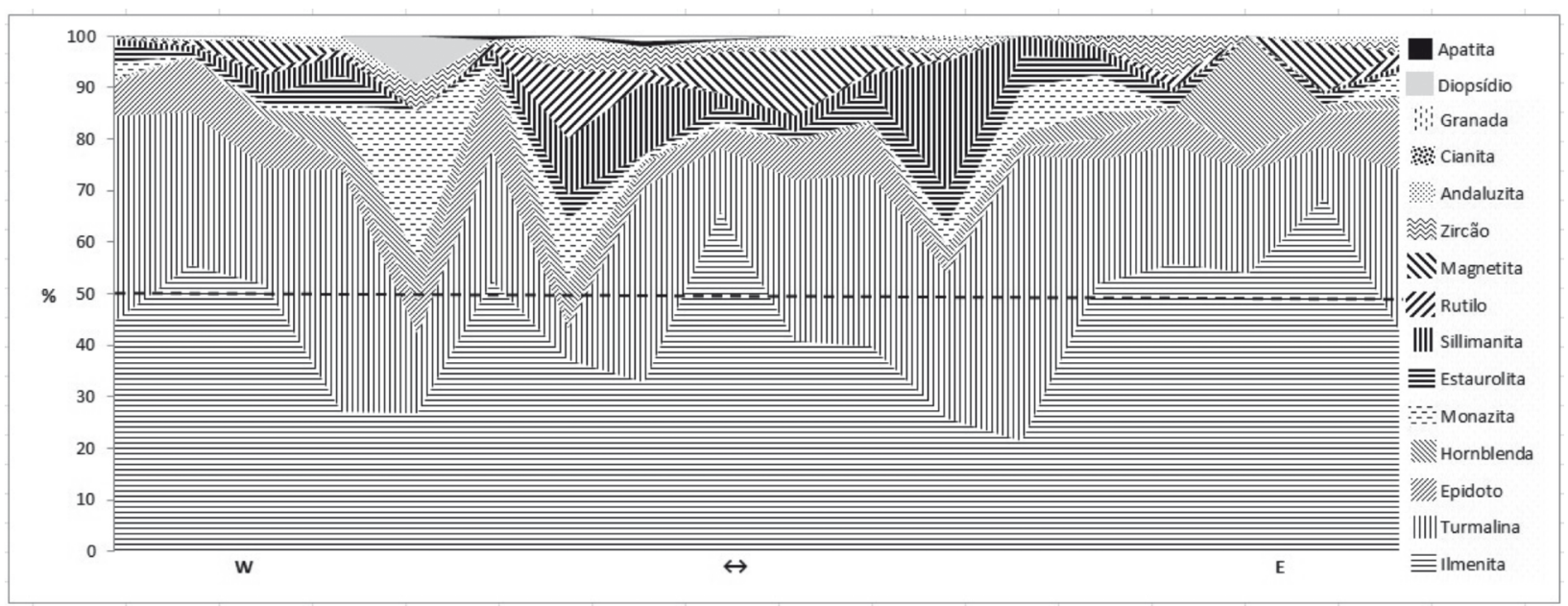

Figura 8. Distribuição de minerais pesados da Folha Acaraú. 


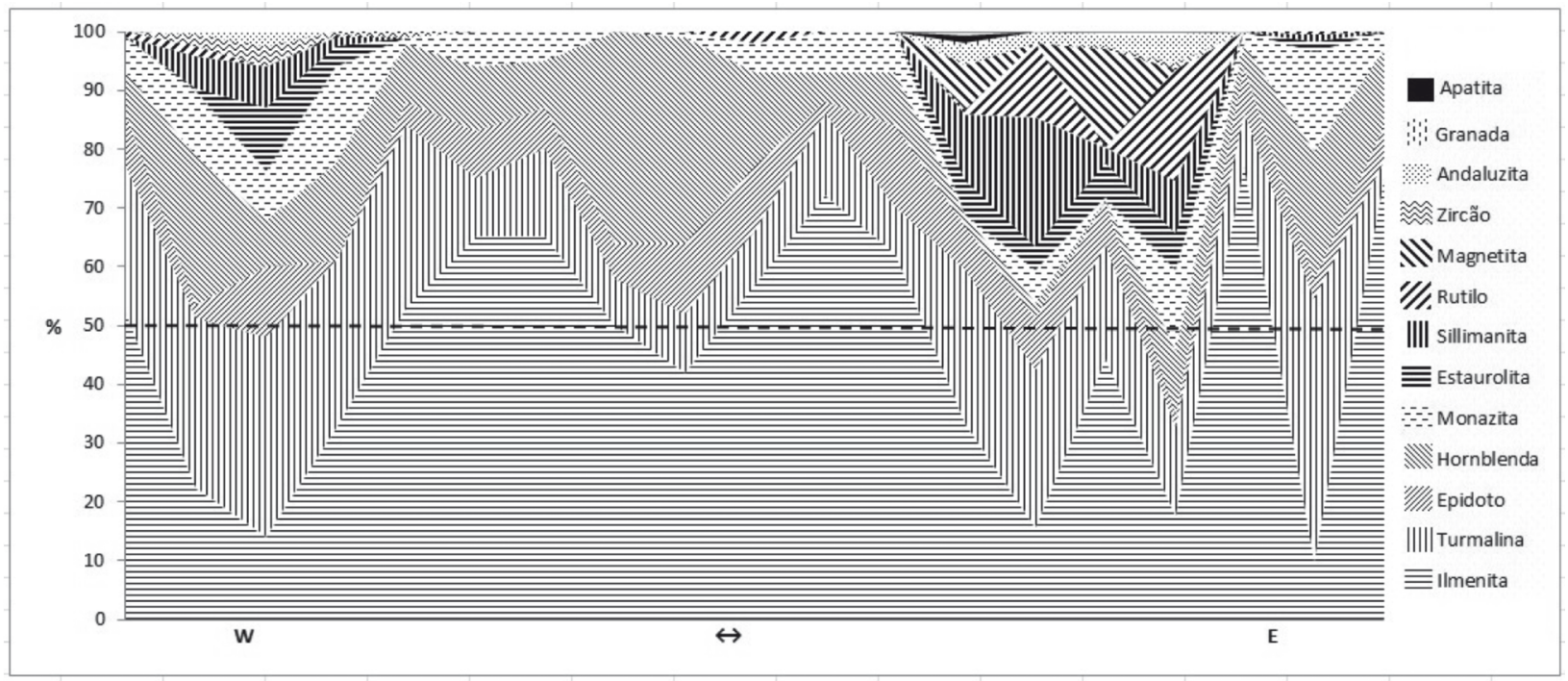

Figura 9. Distribuição de minerais pesados da Folha Itarema.

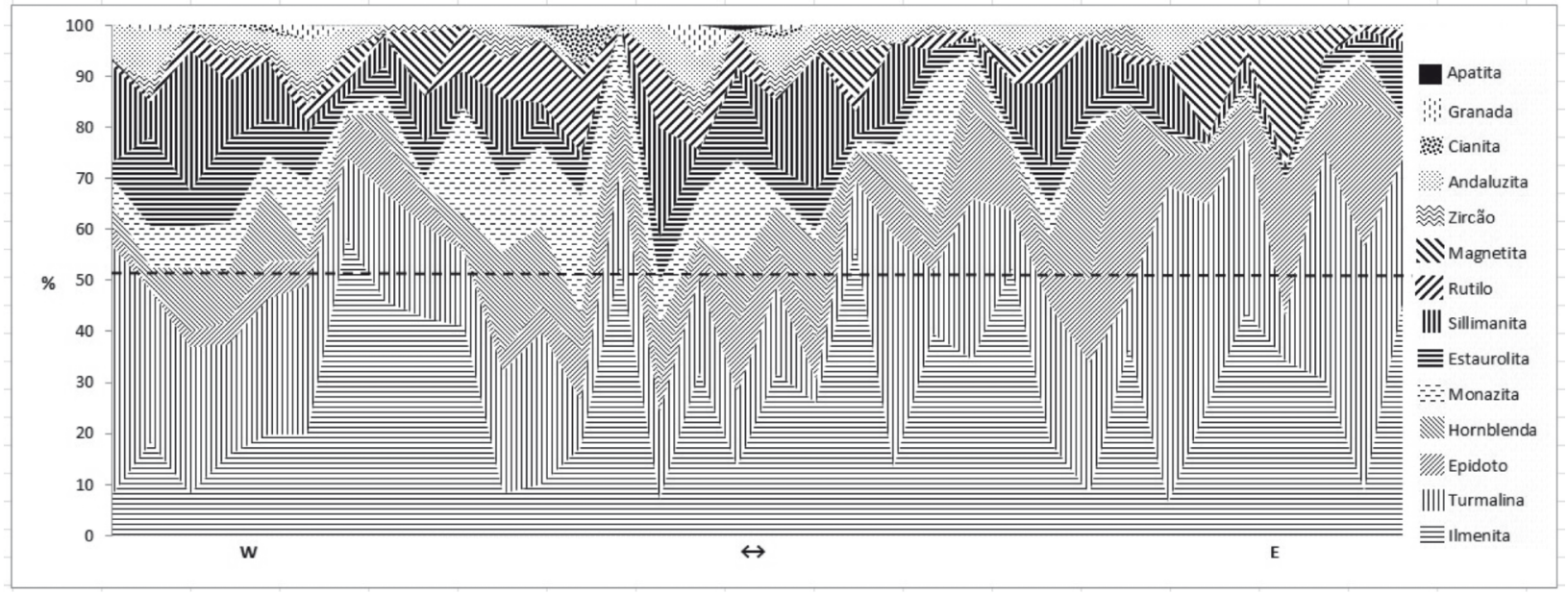

Figura 10. Distribuição de minerais pesados da Folha Fortaleza.

Tabela 1. Dados estatísticos (\%) das espécies minerais identificadas na plataforma continental oeste do Estado do Ceará.

\begin{tabular}{l|cccc}
\hline & Mínimo & Máximo & Média & $\begin{array}{c}\text { Desvio } \\
\text { padrão }\end{array}$ \\
\hline Ilmenita & 6,50 & 77,00 & 40,05 & 18,64 \\
\hdashline Turmalina & 3,00 & 62,00 & 25,59 & 13,32 \\
\hdashline Epídoto & 0,00 & 37,30 & 6,53 & 5,73 \\
\hdashline Anfibólio & 0,00 & 36,00 & 5,93 & 7,44 \\
\hdashline Monazita & 0,00 & 28,90 & 5,30 & 6,13 \\
\hdashline Estaurolita & 0,00 & 24,00 & 4,77 & 4,49 \\
\hline Sillimanita & 0,00 & 27,50 & 4,51 & 6,29 \\
\hline Rutilo & 0,00 & 19,10 & 2,37 & 4,21 \\
\hdashline Magnetita & 0,00 & 24,62 & 1,80 & 4,69 \\
\hdashline Zircão & 0,00 & 8,00 & 1,27 & 1,67 \\
\hdashline Andaluzita & 0,00 & 10,00 & 1,22 & 2,17 \\
\hdashline Cianita & 0,00 & 6,70 & 0,18 & 0,76 \\
\hdashline Granada & 0,00 & 6,00 & 0,16 & 0,72 \\
\hdashline Leucoxênio & 0,00 & 3,50 & 0,11 & 0,49 \\
\hdashline Diopsídio & 0,00 & 9,20 & 0,10 & 0,96 \\
\hdashline Apatita & 0,00 & 1,33 & 0,09 & 0,28 \\
\hdashline Espinélio & 0,00 & 0,61 & 0,02 & 0,11 \\
\hdashline Cassiterita & 0,00 & 0,50 & traços & 0,05 \\
\hline
\end{tabular}

\section{Discussão dos resultados}

$\mathrm{Na}$ plataforma continental oeste cearense constatou-se a predominância de sedimentos biodetríticos (teores de $\mathrm{CaCO}_{3}$ superiores a 50\%, bioclásticos e biolitoclásticos pela classificação de Larsounner, 1977), obedecendo o padrão de sedimentação da Plataforma Continental do Nordeste brasileiro, exceto para a carta Fortaleza e parte da carta Itarema, onde dominaram os sedimentos siliciclásticos (teores de $\mathrm{CaCO}_{3}$ inferiores a $50 \%$, litoclásticos e litobioclásticos pela classificação de Larsounner, 1977). Freire (1985) já relatava que a plataforma continental cearense é a que apresenta maior contribuição de sedimentação terrígena de todas as plataformas nordestinas, pois este aporte terrígeno predomina em toda a plataforma continental interna e, defronte a Fortaleza, chega a alcançar trechos da plataforma continental externa. Esses sedimentos foram retrabalhados e reorganizados em novas feições morfológicas em equilíbrio 
com o regime hidrodinâmico plataformal durante a transgressão holocênica e são nesses sedimentos que tendem a se concentrar os depósitos de pláceres. Na plataforma continental de Fortaleza as areias terrígenas retrabalhadas cobrem quase toda a largura da plataforma continental e areia fluvial retrabalhada ocorre ao largo da desembocadura do Rio Coreaú, existindo áreas de concentrações anômalas de minerais pesados (Palma, 1979). Particularmente na área de estudo, as maiores concentrações estão na carta Fortaleza (Fig. 6), locais onde predominam os sedimentos litoclásticos e litobioclásticos (areias quartzosas médias a finas), com ilhas esparsas de sedimentos bioclásticos, algas e lamas. A influência continental exerce relação direta com esses sedimentos, os quais assumem um caráter reliquiar pelas suas origens do retrabalhamento na plataforma continental durante as variações do nível do mar no Quaternário.

A plataforma continental cearense caracteriza-se pelo baixo gradiente de declividade que é característico e constante, definida como uma região de homogeneidade geomorfológica até aproximadamente a profundidade de $30 \mathrm{~m}$, sendo interrompida por irregularidades nas formas de fundo. Esse declive é o gradiente de passagem do domínio emerso para a plataforma continental, sendo normalmente estreito entre Fortaleza e Pecém, onde a largura é mínima (SETECO, 1996). O MDT (Fig. 5) exibiu essas descontinuidades na morfologia do fundo, diferenciando-se do padrão de rampa da plataforma continental. Essa quebra na monotonia morfológica é explicada pela atuação pretérita de cursos fluviais que interceptavam a costa em níveis de mar mais baixo durante o Quaternário. Vale salientar a relevância dessas feições na gênese dos pláceres marinhos, assim como dos bancos arenosos que ocorrem na plataforma continental interna e favorecem a concentração de minerais pesados nas cavas entre esses bancos. Vales e depressões são comuns na plataforma continental cearense e podem resultar da erosão atual por correntes de turbidez, ou colmatados por sedimentos marinhos (SETECO, 1996).

A proximidade do embasamento cristalino na zona costeira influencia no aporte de minerais pesados para a plataforma continental estudada e esse fato é perceptível na folha Fortaleza onde há predominância dos pláceres (Fig. 6). No litoral cearense, o embasamento cristalino aflora e se projeta para o mar em Jericoacorara, Pecém, Ponta do Mucuripe e Iguape na forma de pontas e promontórios com certa resistência litológica, desempenhando papel relevante no balanço de sedimentos (Morais et al., 2006). As rochas pertencentes ao Complexo
Ceará podem ser as principais responsáveis pelo aporte de minerais pesados concentrados na carta Fortaleza. Essa unidade litoestratigráfica é constituída essencialmente por paraderivadas, predominando metapelitos (biotita gnaisses geralmente com granadas e com cianita e/ou sillimanita), associadas a quartzitos e metacarbonatos em quantidade subordinada, podendo ocorrer raras intercalações de metavulcânicas básicas e ácidas (Garcia \& Arthaud, 2004).

O embasamento cristalino aflora entre -14 e $-28 \mathrm{~m}$ de profundidade nas proximidades do Porto do Pecém, município de São Gonçalo do Amarante (SETECO, 1996), sendo uma importante fonte direta de sedimentos terrígenos onde se originam os pláceres pelo carreamento dos minerais leves e concentração dos pesados pela hidrodinâmica. A constatação desses afloramentos rochosos na plataforma continental foi possível pela análise de sismogramas (Fig. 11), identificando elevações do topo do embasamento onde a espessura do pacote sedimentar nas proximidades da costa é praticamente zero. Esses afloramentos são constituídos por quartzitos, gnaisses, entre outros litotipos do Complexo Ceará, revelando a contribuição do aporte de terrígenos para a plataforma continental tanto em domínio emerso como submerso.

Ilmenita e turmalina são os minerais pesados que predominam na assembleia (Tab. 1, figs. 7 a 10) das cartas Bitupitá e Acaraú (distribuição com as maiores variações acima de $70 \%$ ), Itarema (distribuição com as maiores variações acima de 50 \%) e Fortaleza (cuja distribuição é bem variável, tendo um incremento no extremo leste). Provavelmente um fator determinante para a presença de ilmenita é seu teor nas áreas fontes, já que é um mineral presente em rochas ígneas, metamórficas, areias pretas costeiras e está amplamente distribuído (média 40,05 \%) nos sedimentos da área estudada. A ilmenita comporta-se como um mineral instável quando submetida ao intemperismo químico (Suguio, 2003); contudo, o clima predominante na área de estudo favorece o intemperismo físico nas áreas fonte, não comprometendo a concentração efetiva desse mineral nos sedimentos estudados. A assembleia dos pesados na plataforma continental estudada reflete proveniências regional (retrabalhamento da Formação Barreiras) e local (intemperismo direto das rochas do Complexo Ceará), com contribuições mistas e heterogeneidade intrínseca dos sedimentos pela diversidade mineralógica (Fig. 12). 


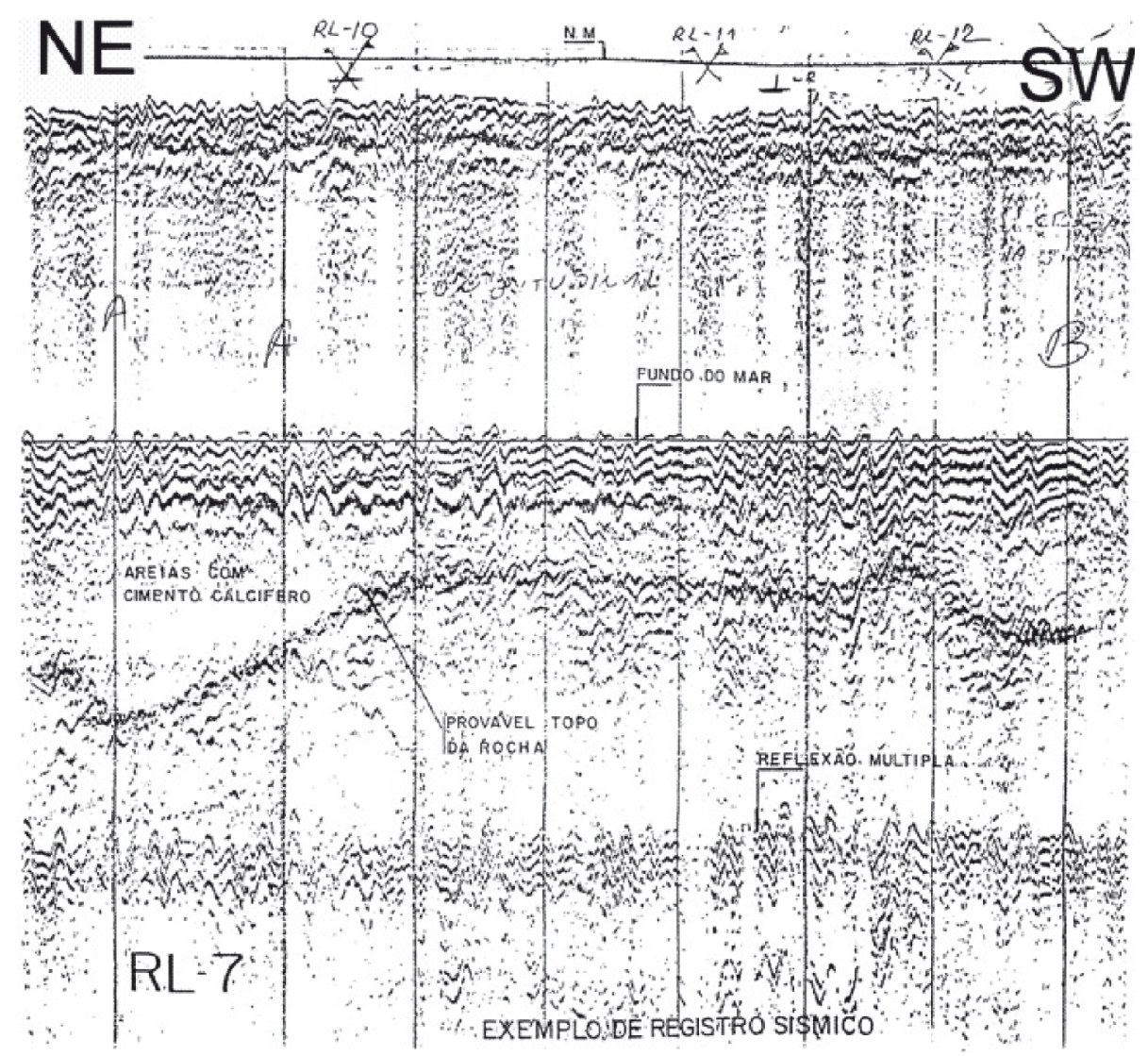

Figura 11. Sismograma da estratigrafia próximo ao Porto do Pecém onde os refletores indicam o topo do embasamento com camadas de areias calcíferas (reprodução extraída de SETECO, 1996).

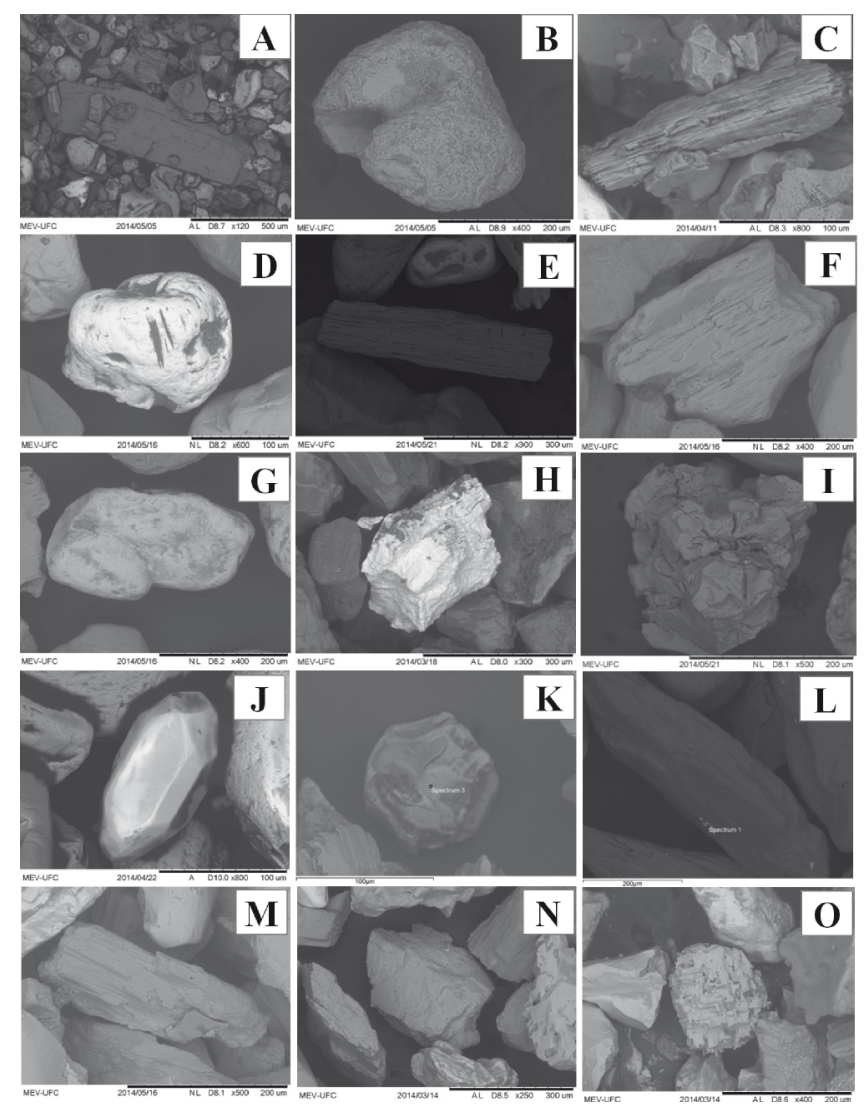

Figura 12. Grãos de minerais pesados imageados em MEV. A) Cianita; B) Rutilo; C) Hornblenda; D) Monazita; E) Silimanita; F) Turmalina; G) Ilmenita; H) Cassiterita; I) Epídoto, J) Zircão; K) Granada; L) Andaluzita; M) Diopsídio; N) Estaurolita; O) Apatita. 
Epídoto, hornblenda, diopsídio, espinélio, granada (almandina), andaluzita, cianita, silimanita, estaurolita, rutilo são espécies indicativas de metamorfismo regional. As seis últimas são comuns em aluviões, considerando que a cianita e o rutilo também são comuns em depósitos litorâneos. Granada, andaluzita, cianita, silimanita, estaurolita e rutilo representam uma assembleia típica de rochas ricas em alumínio; epídoto, diopsídio e espinélio são típicos de calcários metamorfisados; o epídoto pode ser também diagnóstico de hidrotermalismo e de metamorfismo de rochas básicas, além de ocorrer também em rochas ígneas (Pereira et al., 2005; Klein \& Dutrow, 2012). Essa assembleia mineral é compatível com as rochas paraderivadas do Complexo Ceará, Unidade Canindé.

Monazita, zircão, turmalina, magnetita, apatita, cassiterita, ilmenita são espécies predominantes em rochas ígneas. A ilmenita associa-se com magnetita, monazita, zircão e rutilo constituindo as areias pretas que ocorre em áreas costeiras (Klein \& Dutrow, 2012). A turmalina é um mineral típico de pegmatitos graníticos, ocorre em sedimentos marinhos e aluvionares, além de calcários metamórficos. A abundância em turmalina e zircão podem também sugerir retrabalhamento sucessivo de sedimentos antigos (Suguio, 2003; Pereira et al., 2005). A presença localizada de cas- siterita defronte a São Gonçalo do Amarante (Fig. $12 \mathrm{H}$ ) fortalece a ideia de área-fonte bastante próxima $(0,5-1 \mathrm{Km})$ devido à alta densidade $(\sim 7,15$ $\mathrm{g} / \mathrm{cm}^{3}$ ) dificultar seu deslocamento para longas distâncias.

A análise de agrupamento forneceu as primeiras constatações sobre as paragêneses minerais através das associações lineares entre os minerais pesados na plataforma continental estudada. 0 dendograma (Fig. 13) mostrou associações entre minerais quimicamente estáveis e menos estáveis, como por exemplo zircão, granada e andaluzita; rutilo, monazita, apatita e cianita. Uma explicação seria a deposição e transporte de sedimentos atuais juntamente com o retrabalhamento de sedimentos antigos na área de estudo, todos tendo sua dispersão mecânica influenciada pela densidade de cada mineral e energia de ondas e correntes oceânicas. A maioria dos minerais pesados revelou proveniência de rochas metamórficas, próximas ou afastadas do ambiente de deposição pela paragênese hornblenda, silimanita, granada, andalusita, estaurolita, cianita, rutilo e epídoto. Vale ressaltar a ocorrência de afloramentos do embasamento (Complexo Ceará) na plataforma continental próximo do Porto do Pecém contribuindo diretamente como fontes de minerais pesados para os pláceres nesses locais.

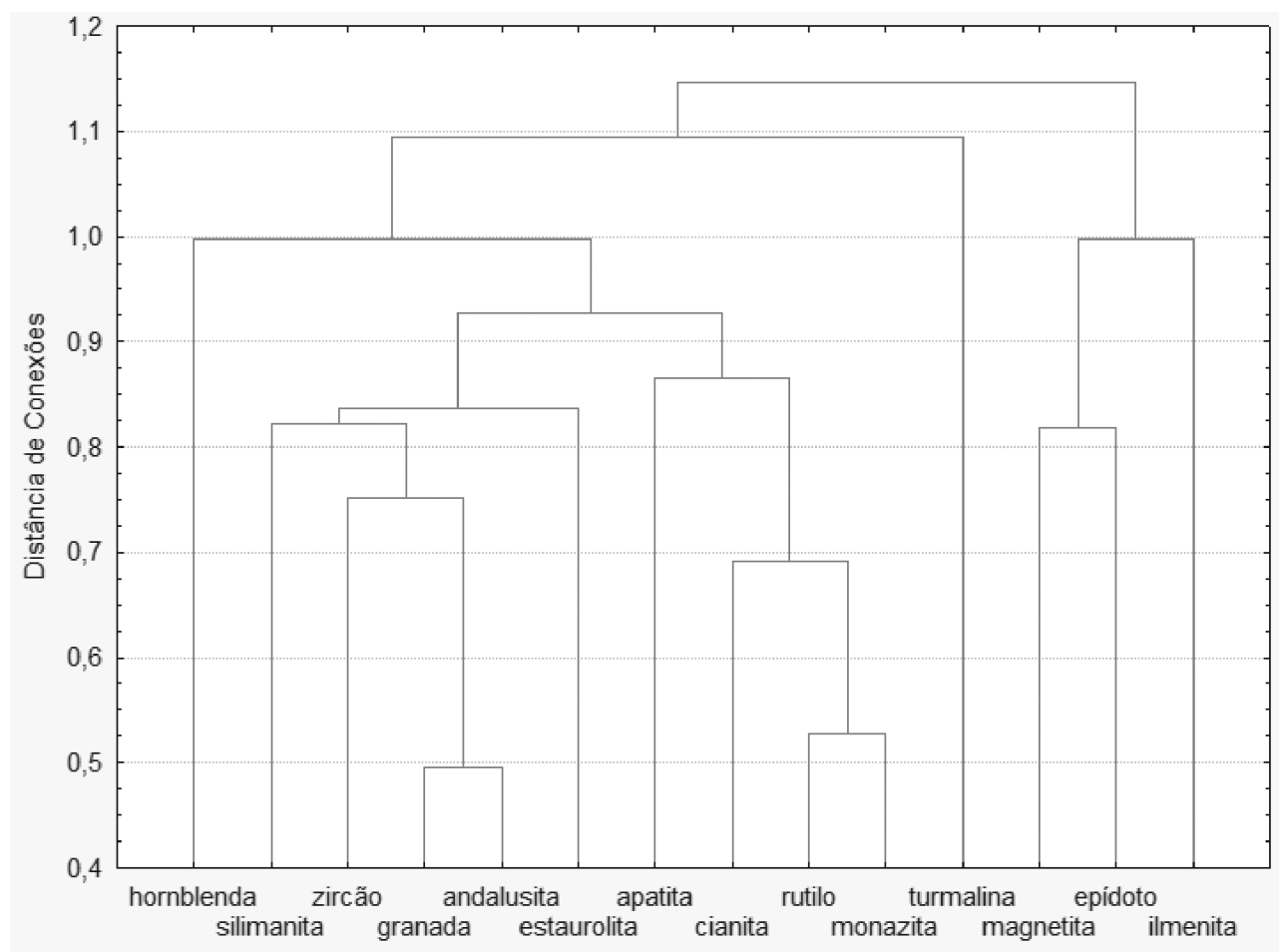

Figura 13. Dendrograma da assembleia de minerais pesados da plataforma continental oeste do Ceará. 
A análise de Componentes Principais (Fig. $14)$ revelou que os minerais pesados de maior variância no eixo principal, com 20,16 \% do total das variâncias, são: ilmenita, magnetita e epídoto. Esses minerais pesados não necessariamente apresentam correlações entre si, provavelmente seja característica da dinâmica do ambiente. 0 epídoto é um mineral indicador de condições hidrotermais cristalizado em todas as condições de metamorfismo regional (Pereira et al., 2005). Magnetita e ilmenita são minerais cristalizados em variados tipos de rochas, contudo podem ocorrer associados em um mesmo sedimento (Suguio, 2003). Na segunda componente principal, com $13,27 \%$ da variância total das amostras, os minerais de maior variância são: rutilo, monazita, cianita e apatita. As duas primeiras componentes representam variabilidade suficiente que pode indicar um padrão a ser interpretado.

A associação estaurolita, cianita, silimanita, granada e rutilo reflete metamorfismo regional de médio a alto grau na fácies anfibolito em ambiente químico aluminoso (Klein \& Dutrow, 2012), reforçando essa paragênese como diagnóstico das rochas pertencentes ao Complexo Ceará. Rutilo, monazita, cianita e zircão reunidos no componente 2 caracterizam areias negras praiais, onde é comum essa associação mineralógica.

As análises de agrupamento e de componentes principais sugeriram que a assembleia mineral que ocorre na área de estudo se comporta de acordo com o regime hidrodinâmico, caracterizado pela alta dispersão dos sedimentos e caráter de natureza dual da proveniência desses minerais pesados (fontes de origem sedimentar e de rochas do embasamento cristalino). Corroboram com essa constatação grãos de zircão de fonte ígnea (euedral) e de alta reciclagem sedimentar (arredondado) em áreas pontuais próximas à Fortaleza (Fig. 15). Esse fato revela a complexidade para inferir uma área-fonte, mesmo restringindo espacialmente a malha amostral para as várias associações minerais contempladas nesse estudo.

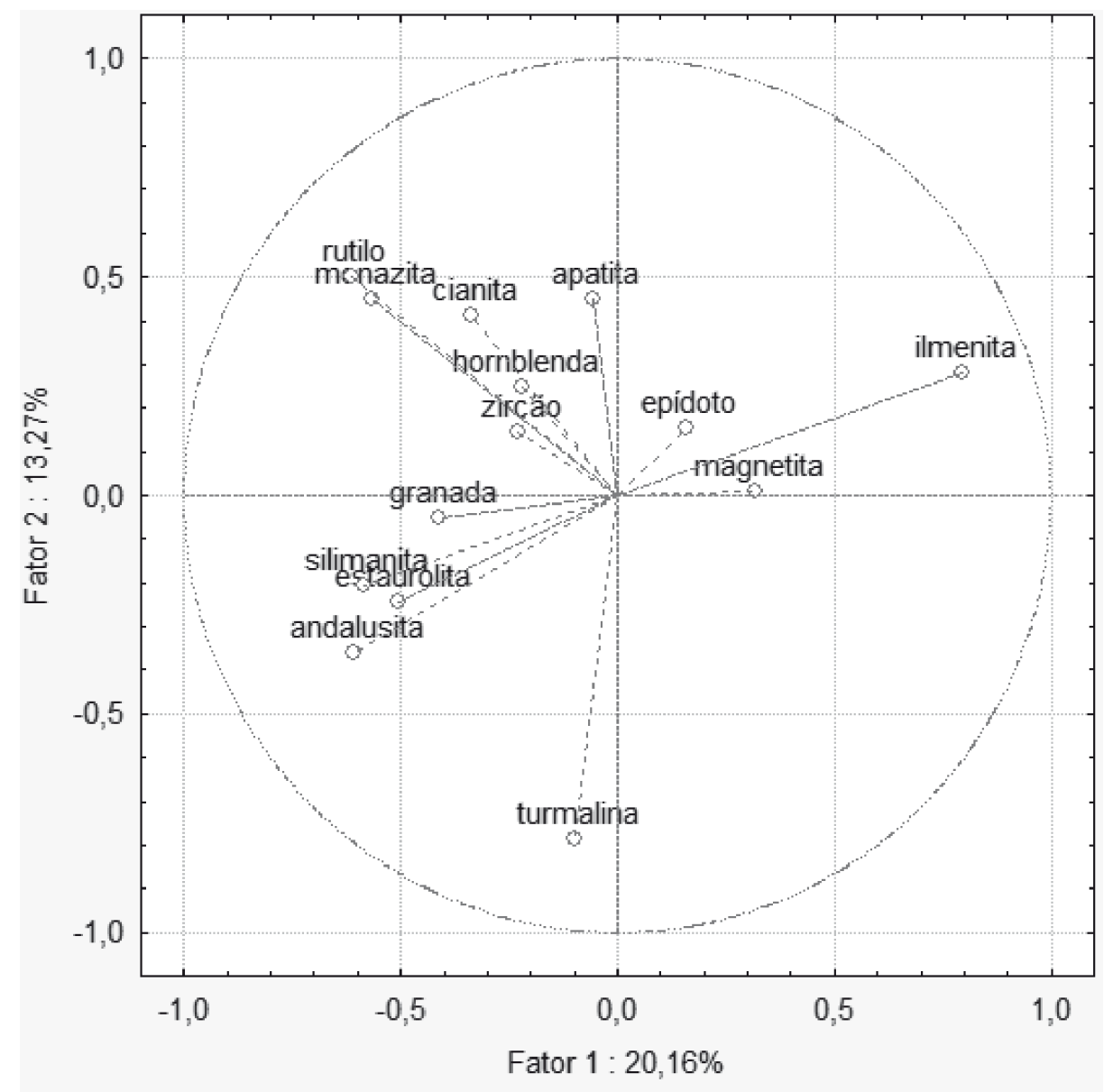

Figura 14. ACP da assembleia de minerais pesados da plataforma continental oeste do Ceará. 

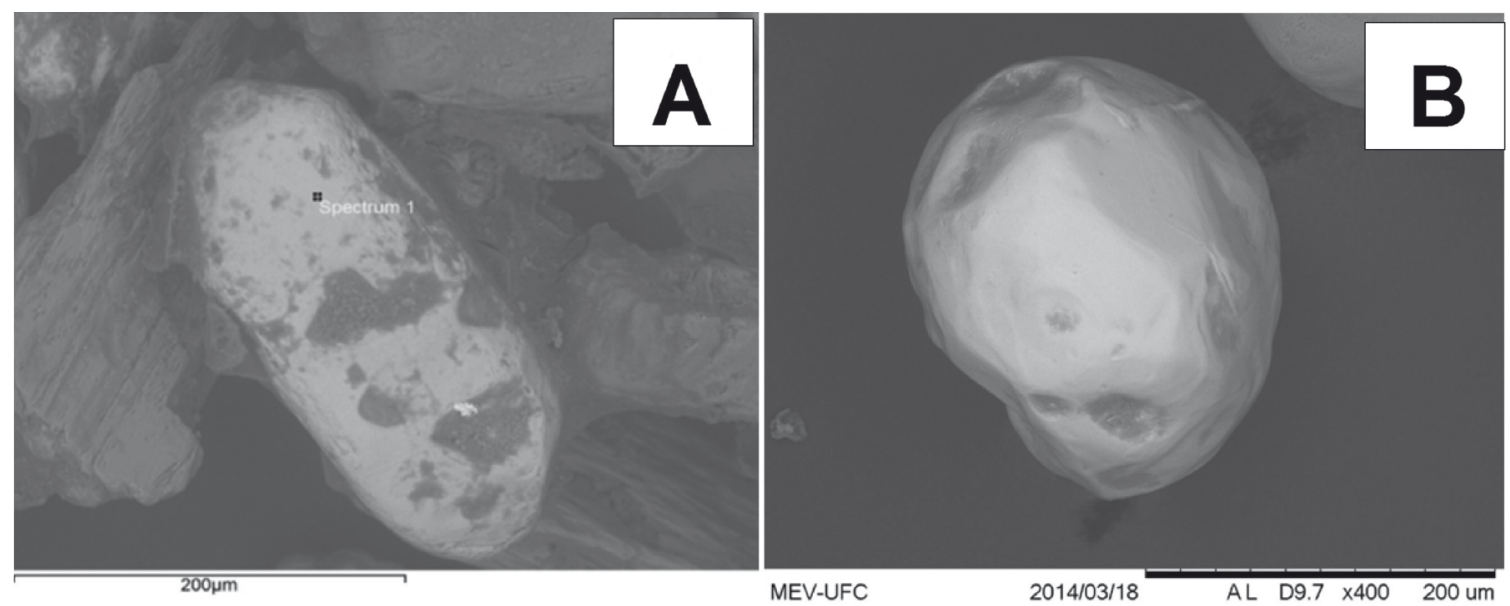

Figura 15. Zircão euedral (A) e arredondado (B), ao longo do litoral de São Gonçalo do Amarante.

A análise de fatores (Tab. 2) produz um número que corresponde às associações minerais que refina os limites de províncias deposicionais para as espécies minerais envolvidas (Wong, 2002). No grupo de minerais pesados representado pelo $\mathrm{Fa}$ tor 1 , ilmenita e magnetita se destacam com fortes correlações. Esta associação geralmente ocorre em depósitos litorâneos onde esses minerais pesados encontram-se pré-concentrados em um mesmo sedimento. No grupo representado pelo Fator 2, ilmenita, monazita, rutilo, cianita e apatita podem caracterizar areias negras praiais. Ressalta-se a falta de afinidade da turmalina nesse grupo pela forte correlação negativa. No Fator 3 destacam-se turmalina, monazita e hornblenda que pode ser compatível com a mineralogia de rochas ígneas. No Fator 4, o grupo de minerais composto pela sillimanita, epídoto e hornblenda é indicativo de metamorfismo regional, provavelmente diagnóstico das rochas paraderivadas do Complexo Ceará, Unidade Canindé.
Uma forma de ordenar as diversas fontes que originaram os pláceres marinhos na área de estudo é considerar as rochas do Complexo Ceará como fonte primária de sedimentos, seguido por fontes secundárias (retrabalhamento da Formação Barreiras, areias pretas dos depósitos praiais e sedimentos marinhos de deriva litorânea). As intercorrelações estatísticas oriundas das análises de agrupamento, componentes principais e de fatores, juntamente com as peculiaridades do ambiente estudado (heterogeneidade, grau de dispersão dos sedimentos plataformais e dinâmica do ambiente), serviram para caracterizar a área-fonte que por sua vez possui uma natureza dual. Deve-se ainda considerar o aporte fluvial pretérito (paleocanais) e atual na origem das concentrações de minerais pesados na plataforma continental estudada e a forma como todos os fatores anteriormente descritos interagem num ambiente extremamente dinâmico que revela a complexidade e diversidade mineralógica na gênese desses depósitos.

Tabela 2. Análise de fatores das espécies minerais identificadas na plataforma continental oeste do Estado do Ceará

\begin{tabular}{l|cccc}
\hline Variáveis & Fator 1 & Fator 2 & Fator 3 & Fator 4 \\
\hline Ilmenita & 0,797144 & 0,282732 & $-0,195766$ & $-0,286681$ \\
\hdashline Turmalina & $-0,099976$ & $-0,784730$ & 0,292839 & $-0,186600$ \\
\hdashline Monazita & $-0,564040$ & 0,448949 & 0,268644 & $-0,151127$ \\
\hdashline Estaurolita & $-0,505047$ & $-0,241636$ & $-0,092336$ & $-0,441634$ \\
\hdashline Andalusita & $-0,608409$ & $-0,360298$ & $-0,412970$ & 0,175865 \\
\hdashline Silimanita & $-0,586627$ & $-0,204047$ & 0,026508 & 0,406134 \\
\hdashline Epídoto & 0,158508 & 0,154632 & $-0,201267$ & 0,615981 \\
\hdashline Hornblenda & $-0,221935$ & 0,247473 & 0,521557 & 0,535776 \\
\hdashline Zircão & $-0,230912$ & 0,143551 & $-0,586446$ & 0,116301 \\
\hdashline Rutilo & $-0,614108$ & 0,500503 & 0,031394 & $-0,132303$ \\
\hdashline Cianita & $-0,336418$ & 0,412037 & 0,046073 & $-0,258280$ \\
\hdashline Apatita & $-0,056521$ & 0,450033 & $-0,166023$ & $-0,085443$ \\
\hdashline Granada & $-0,409376$ & $-0,049873$ & $-0,593383$ & $-0,130374$ \\
\hline Magnetita & 0,317614 & 0,009465 & $-0,474683$ & 0,216034 \\
\hline
\end{tabular}




\section{Conclusões}

Os minerais pesados da plataforma continental oeste cearense tendem a se concentrar na parte mais a leste da área (Folha Fortaleza) com teores de até 4,54 \% na fração analisada e representados pelas espécies: ilmenita, turmalina, epídoto, hornblenda, monazita, estaurolita, sillimanita, rutilo, magnetita, zircão, andaluzita, cianita, granada, leucoxênio, diopsídio, apatita, espinélio e cassiterita. As concentrações de minerais pesados localizam-se predominantemente nas areias litoclásticas e litobioclásticas, em profundidades inferiores a 20 $m$, levando-se em consideração as irregularidades do fundo marinho e significativa deposição de ilmenita e turmalina, que juntamente com as demais espécies forneceram informações sobre as áreas-fonte desses depósitos.

A contribuição local (primária) é atribuída às rochas metamórficas do Complexo Ceará que tanto ocorre próximo à costa em domínio continental como aflora na plataforma continental nas proximidades do Porto do Pecém (São Gonçalo do Amarante) em profundidades de -14 e -28 m. A Formação Barreiras, pela sua extensão na zona costeira, contribui de forma regional no aporte dos sedimentos marinhos, que juntamente com as areias pretas dos depósitos praiais e os sedimentos marinhos de deriva litorânea, correspondem às contribuições secundárias dos pláceres marinhos objeto desse estudo. A estatística multivariada expôs pelas análises de agrupamento e de componentes principais que a deposição de sedimentos atuais e de sedimentos retrabalhados mais antigos são sincrônicos e influenciados pela dinâmica do ambiente. A análise de fatores sugeriu a discriminação de dois tipos de proveniências pelas associações das variáveis nos fatores 1 e 2 como proveniência dos sedimentos praiais e fatores 3 e 4 correspondentes às rochas do Complexo Ceará. Contudo deve-se considerar como características mais marcantes a heterogeneidade e o grau de dispersão dos sedimentos plataformais que se unem a dinâmica do ambiente e áreas-fonte mistas, aliados ainda ao aporte fluvial pretérito (paleocanais) e atual para o ambiente plataformal.

Agradecimentos - Este estudo constitui parte da tese de doutorado do primeiro autor, desenvolvida no Programa de Pós-graduação em Geologia da Universidade Federal do Ceará. Os autores agradecem aos revisores do trabalho, aos editores da revista Pesquisa em Geociências e à Coordenação de Aperfeiçoamento de Pessoal de Nível Superior pela bolsa de doutorado concedida.

\section{Referências}

Addad, J.E. 2010. Minerais Pesados: uma ferramenta para prospecção, proveniência, paleogeografía $e$ análise ambiental. São Paulo, Edição Independente, 208p.

Almeida, N.M., Lehugeur, L. G. O., Freire, G. S. S., Santos, D. M. \& Aguiar Neto, A. B. 2011. Assembléia de Minerais Pesados da Plataforma Continental - Porção Oeste do Estado do Ceará, Brasil. Revista de Geologia, 24(1): 21-27.

Andriotti, J.L.S. 1997. Análise de Componentes Principais: Fundamentos de uma técnica de análise de dados multivariada aplicável a dados geológicos. Acta Geologica Leopoldensia, 20(44): 27-50.

Barreto, L.A., Milliman, J.D., Amaral, C.A.B. \& Francisconi, 0.1975. Upper continental margin sedimentation of Brazil. Contributions to Sedimentology, 4: 11-43.

Cavalcanti, V.M.M. 2011. Plataforma continental: a última fronteira da mineração brasileira. Brasília, DNPM, 104p.

Conceição, J.C., Zálan, P.V. \& Wolf, S. 1988. Mecanismo, evolução e cronologia do rift sul-atlântico. Boletim de Geociências da Petrobrás, 2(2/4): 255-265.

Corrêa, I.C.S., Ayup-Zouain, R.N., Weschenfelder, J. \& Tomazelli, L.J. 2008. Áreas Fontes dos Minerais Pesados e sua Distribuição sobre a Plataforma Continental Sul-brasileira, Uruguaiana e Norte-argentina. Pesquisas em Geociências, 35(1): 137-150.

Emery, K.O. \& Noakes, L.C. 1968. Economic placer deposits of the continental shelf. Technical Bulletin Economic Comission for Asia and Far East, 1: 95-110.

França, A.M.C., Coutinho, P.N. \& Morais, J.O. 1976. Sedimentos superficiais da margem continental nordeste brasileira. Brazilian Journal of Geology, 6(2): 7188.

Freire, G.S.S. 1985. Geologia Marinha da Plataforma Continental do Estado do Ceará. Recife, 108p. Dissertação de Mestrado, Programa de Pós-graduação em Geociências, Instituto de Geociências, Universidade Federal de Pernambuco.

Galehouse, J.S. 1971. Point counting. In: Carver, R. E. (Ed.). Procedures in Sedimentary Petrography. New York, Wiley-Interscience, p. 385-407.

Garcia, M.G.M. \& Arthaud, M.H. 2004. Caracterização de trajetórias P-T em nappes brasilianas: região de Boa Viagem/Madalena - Ceará Central (NE Brasil). Revista de Geologia, 17(2): 173-191.

Gent, M. R., Alvarez, M. M., Iglesias, J. M. G. \& Alvarez, J. T. 2005. Offshore Ocurrences of Heavy-Mineral Placers, Northwest Galicia, Spain. Marine Georesources and Geotechnology, 23: 39-59.

Klein, C. \& Dutrow, B. 2012. Manual de ciência dos minerais; tradução e revisão técnica. Porto Alegre, Bookman, 706p.

Kudrass, H.R. 2000. Marine placer deposits and sea-level changes. In: Cronan, D.S. (Ed.). Handbook of Marine Mineral Deposits. Boca Raton, CRC Press, p. 3-26.

Lalomov, A.V. \& Tabolitch, S.E. 2000. Age determination of coastal submarine placer, Val'cumey, northern Si- 
beria. CEN Technical Journal, 14(3): 83-90

Lamas, F., Irigaray, C., Oteo, C. \& Chacon, J. 2005. Selection of the most appropriate method to determine the carbonate content for engineering purposes with particular regard to marls. Engineering Geology, 81: 32-41.

Larsonneur, C. 1977. La cartographie de's dépots meubles sur le plateau continental français: méthode mise du points et utilisée en Manche. Journal de Recherche Oceanographique, 2: 34-39.

Lewis, G.R. 1924. The Stannaries: a study of the English Tin Miner. Cambridge, Harvard University Press, 335p.

Martins, L.R. \& Coutinho, P.N. 1981. The Brazilian Continental margin. Earth Science Reviews, 17: 87 -107.

Milani, E.J., Brandão, J.A.S.L., Zalán, P.V. \& Gamboa, L.A.P. 2001. Petróleo na margem continental brasileira: geologia, exploração, resultados e perspectivas. $R e$ vista Brasileira de Geofísica. 18(3): 352-396.

Morais, J.O., Freire, G.S.S., Pinheiro, L., Souza, M.J.N., Carvalho, A.M., Pessoa, P.R. \& Oliveira, S.H.M. 2006. Erosão e progradação do litoral brasileiro: Ceará. In: Muehe, D. (Ed.). Erosão e Progradação do Litoral Brasileiro, 2006, Brasília. p. 132-154. Disponível em: <http://www.mma.gov.br/estruturas/sqa_sigercom/_publicacao/78_publicacao12122008085953. pdf> Acesso em: 03 out. 2014.

Palma, J.C. 1979. Depósitos de Minerais Pesados. Rio de Janeiro, Série Projeto REMAC, 10, p. 33-50 (Relatório Final).

Parfenoff, A., Pomerol, C. \& Toureng, J. 1970. Les minéraux en grains - Méthodes d'études et determi-

Man 564

Editores: Ana Maria P. Mizusaki \& Maria do Carmo

Lima e Cunha. nation. Paris, Masson et Cie, 578p.

Pereira, R.M., Ávila, C.A. \& Lima, P.R.A.S. 2005. Minerais em grãos. Técnicas de coleta, preparação e identificação. São Paulo, Oficina de Textos, 128p.

Secretaria dos Transportes, Energia, Comunicação e Obras 1996. Estudo de Impacto Ambiental - EIA: obras off-shore do Porto de Pecém. Fortaleza, 3 (A e B), 355p.

Silva, C.G. 2000. Placeres Marinhos. Brazilian Journal of Geophysics, 18(3): 327-336.

Silva, A.M.C. 2005. Relações entre a dinâmica costeira e a meio fauna dos sedimentos praiais do litoral da Ilha de Itamaracá, PE. Recife, 139p. Tese de Doutorado, Programa de Pós-graduação em Geociências, Instituto de Geociências, Universidade Federal de Pernambuco.

Silva Filho, W.F. 2004 Domínios Morfoestruturais da Plataforma Continental do Estado do Ceará. Porto Alegre, 307p. Tese de Doutorado, Programa de Pós-graduação em Geociências, Instituto de Geociências, Universidade Federal do Rio Grande do Sul.

Suguio, K. 2003. Geologia Sedimentar. São Paulo, Edgard Blücher, 400p.

Tomazzoli, E.R., Oliveira, U.R. \& Horn Filho, N.O. 2007. Proveniência dos Minerais de Óxidos de Fe-Ti nas Areias da Praia do Pântano do Sul, Ilha de Santa Catarina (SC), Sul do Brasil. Revista Brasileira de Geofísica, 25(Supl. 1): 49-64.

Wong, F.L, 2002. Heavy minerals from the Palos Verdes margin, southern California. Continental Shelf Research, 22: 899-910. 
